\title{
Kemampuan Representasi Siswa SMP pada Materi Pesawat Sederhana
}

\author{
Ayu Nurindah Sari ${ }^{1}$, Oka Elvina ${ }^{2}$, Arifian Dimas ${ }^{3}$ \\ ${ }^{1,2,3}$ Program Studi Pendidikan IPA STKIP Modern Ngawi, INDONESIA \\ Email : ayunrndhsari.15@gmail.com, okaelvina11@gmail.com
}

\begin{abstract}
This study aims to determine the ability of student representation on Simple Airplane material. The research method used is descriptive qualitative. The population in this study was grade VIII students of MTS Al-Hidayah Kendal Ngawi in the academic year 2019/2020. Sampling uses purposive random sampling. The sample used was class VIII A, with a total of 26 students. The test instruments used in this study were tests and interviews. The test is in the form of multiple-choice reasoning which amounts to 10 simple aircraft material questions. Interviews conducted after researchers got test results from students. The representations examined in this study were image representations and verbal representations. The results showed that the ability of students' representation was still low. The evidenced by the results of student tests where most of the achievements are still below 50\%. Lack of student ability in terms of multi-representation because students not accustomed to using representation in understanding concepts.
\end{abstract}

Keywords: Representation, Simple Machine

\begin{abstract}
Abstrak: Penelitian ini bertujuan untuk mengetahui kemampuan representasi siswa pada materi Pesawat Sederhana. Metode penelitian yang digunakan adalah deskriptif kualitatif. Populasi pada penelitian ini siswa kelas VIII MTS Al-hidayah Kendal Ngawi tahun akademik 2019/2020. Pengambilan Sample menggunakan purposive random sampling. Sample yang digunakan adalah kelas VIII A dengan jumlah 26 siswa. Instrumen tes yang digunakan dalam penelitian ini adalah tes dan wawancara. Tes berupa pilihan ganda beralasan yang berjumlah 10 soal materi pesawat sederhana. Wawancara dilakukan setelah peneliti mendapatkan hasil tes dari siswa. Representasi yang dikaji dalam penelitian ini adalah representasi gambar dan representasi verbal. Hasil penelitian menujukkan bahwa kemampuan multirepresentasi siswa masih rendah. Hal ini dibuktikan dengan hasil tes siswa yang sebagian besar ketercapaian masih dibawah 50\%. Kurangnya kemampuan siswa dalam hal multirepresentasi dikarenakan siswa belum terbiasa menggunakan representasi dalam memahami konsep.
\end{abstract}

Kata Kunci: Representasi, Pesawat Sederhana

\section{PENDAHULUAN}

Pendidikan adalah usaha untuk menyiapkan peserta didik melalui kegiatan bimbingan, pengajaran (Oemar Hamalik, 2008). Pendidikan dalam arti luas adalah suatu proses dengan metode-metode tertentu untuk memperoleh pengetahuan, pemahaman dan cara bertingkah laku yang sesuai dengan kebutuhan (muhibin syah, 2013). Pembelajaran di Indonesia saat ini menggunakan kurikulum 2013 (K-13). Kurikulum 2013 memiliki empat aspek penilaian, yaitu aspek pengetahuan, aspek keterampilan, aspek sikap, dan perilaku. Pada Kurikulum 2013, pembelajaran ditekankan kepada proses dalam mencari konsep yang dipelajari. Pembelajaran IPA adalah ilmu yang mempelajari peristiwa-peristiwa yang terjadi di alam dengan melakukan observasi, eksperimentasi, penyimpulan. Namun dalam pelaksanaanya, guru masih kurang memberikan penekanan terhadap kegiatan siswa khususnya dalam kegiatan representasi. Representasi adalah mekanisme tentang penggambaran suatu konsep ke 
berbagai bentuk representasi lain atau multirepresentasi. Loviza mengatakan bahwa terdapat beberapa representasi diantaranya:

A. Deskripsi verbal

Untuk memberikan definisi dari suatu konsep, verbal adalah satu cara yang tepat untuk digunakan dalam suatu pembelajaran atau penarik suatu kesimpulan.

B. Gambar atau diagram

Gambar membantu memvisualisasikan sesuatu yang masih bersifat abstrak. Dalam fisika bentuk diagram yang digunakan disesuaikan dengan konsep pelajaran. Misalnya benda bebas, diagram muka gelombang, dsb.

C. Grafik

Grafik dapat mempersingkat penjelasan yang panjang mengenai suatu konsep. Akan tetapi penggunaan grafik memerlukan suatu kemampuan yang tinggi bagi siswa dalam menginterpretasikan konsep.

D. Matematik

Matematik dibutuhkan dalam menyelesaikan persoalan kuantitatif. Penggunaan representasi matematik ini misalnya menerapkan rumus-rumus fisika dalam menyelesaikan soal-soal fisika serta memerlukan penguasaan matematik yang baik.

Representasi siswa adalah bagian integral dari mempelajari konsep fisika. Deskripsi beberapa representasi adalah bentuk untuk menggambarkan, mewakili, atau melambangkan sesuatu, objek atau proses (Ainswort, 2006). Multirepresentasi sebagai praktik untuk merepresentasikan konsep yang sama melalui berbagai cara, yang meliputi deskriptif tentang representasi (verbal, grafik, tabel), eksperimental, matematika, figuratif (bergambar, analogi, dan metaforis), kinestetik, visual, dan operasional (Waldrip, 2006). Fungsi utama dari beberapa representasi adalah pujian, hambatan interpretasi, dan pembangun pemahaman (Ainswort, 2006).. Representasi juga dapat membantu siswa dalam memahami konsep (Izsak, 2003)]. Pembelajaran fisika bertujuan untuk mendapatkan pemahaman tentang ide, dan aplikasinya(Reif,1995). Pembelajaran representasi berganda memungkinkan pembentukan makna dalam karya-karya memori yang memungkinkan siswa untuk secara bersamaan mempersepsikan kata-kata dan gambar (Mayer, 2003)

Berdasarkan penelitian sebelumnya bahwa kemampuan untuk memecahkan masalah dalam fisika dapat menggunakan beberapa representasi seperti matematika, verbal (tertulis atau lisan) dan visual (simbol / notasi, gambar, dan grafik) (Wieman dkk, 2015). Penggunaan multirepresentasi dalam mempelajari konsep-konsep spesifik memungkinkan pemahaman yang tepat tentang konsep-konsep tersebut dan proses komunikasi selanjutnya. Dalam fisika, beberapa representasi berarti pemahaman yang lebih baik tentang bagaimana sistem dan metode bekerja, dan kemudian mengkomunikasikannya kepada sesama siswa atau guru (Meltzer, 2005). Kesimpulan bahwa multirepresentasi memungkinkan siswa untuk mengembangkan pengetahuan dan pemecahan masalah. Oleh karena itu, mengembangkan kemampuan representasional untuk menyelesaikan masalah adalah solusi yang tepat untuk proses pembelajaran aktif.

Beberapa peneliti menggunakan beberapa representasi dalam pembelajaran fisika, dan meneliti dampak subjeknya pada berbagai aspek pembelajaran. Hasil penelitian oleh Natasa Erceg (2012) menunjukkan bahwa dalam semua kelompok siswa mengalami kesulitan dalam menghubungkan grafik dengan konsep kinematika. Tantangan utama adalah (i) menggabungkan fitur-fitur penting dari gambar (tinggi, kemiringan, area di bawah diagram) dengan kuantitas fisik yang sesuai (kecepatan, akselerasi, perpindahan), (ii) memahami 
kecepatan dan percepatan seiring dengan banyaknya vektor yang memiliki arah dan besarnya, iii) ketidakmampuan untuk memvisualisasikan gerakan nyata berdasarkan representasi grafis. Grafik fungsi linear dan harmonik dapat memudahkan siswa dalam memahami materi osilasi, tetapi dalam proses menggambar diagram siswa membutuhkan pemahaman yang matang dalam membaca grafik, sehingga mengetahui makna grafik (Dewi dkk, 2018).

\section{METODE PENELITIAN}

Metode penelitian yang digunakan adalah deskriptif kualitatif. Populasi pada penelitian ini siswa kelas VIII MTS Al-hidayah Kendal Ngawi tahun akademik 2019/2020. Pengambilan Sample menggunakan purposive random sampling. Sample yang digunakan adalah kelas VIII A dengan jumlah 26 siswa. Instrumen tes yang digunakan dalam penelitian ini adalah tes dan wawancara. Tes berupa pilihan ganda beralasan yang berjumlah 10 soal materi pesawat sederhana. Wawancara dilakukan setelah peneliti mendapatkan hasil tes dari siswa. Representasi yang dikaji dalam penelitian ini adalah representasi gambar dan representasi verbal.

\section{HASIL DAN PEMBAHASAN}

Berdasarkan analisis data yang diperoleh, persentase jawaban benar siswa disajikan pada grafik dibawah ini

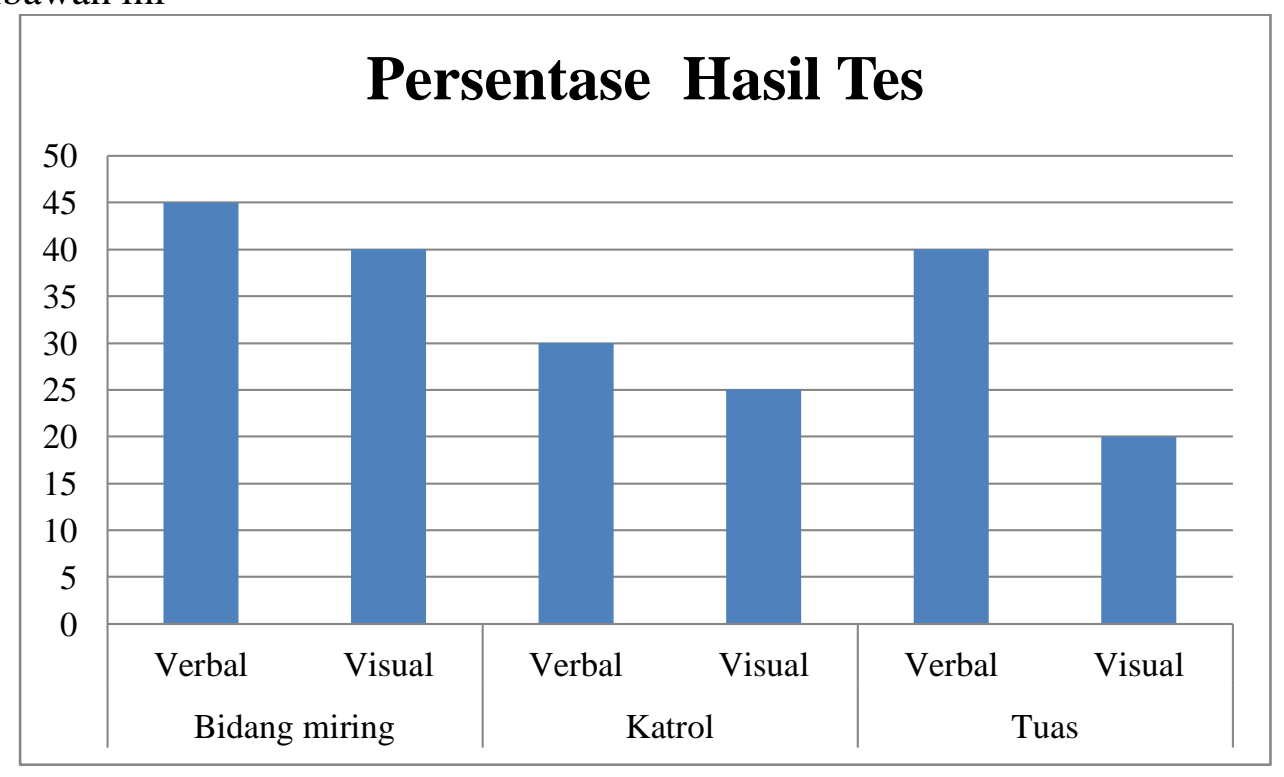

Grafik 1. Persentase jawaban siswa

Grafik 1 dapat dilihat bahwa pada materi bidang miring pada soal verbal $45 \%$ siswa menjawab benar, dan soal visual $40 \%$ siswa menjawab benar. Pada materi katrol pada soal verbal 30\% siswa menjawab benar, dan soal visual 30\% siswa menjawab benar. Pada materi Tuas pada soal verbal $40 \%$ siswa menjawab benar, dan soal visual $20 \%$ siswa menjawab benar.Hal ini menunjukkan bahwa sebagian besar siswa masih mengalami kesulitan dalam menyelesaikan soal dalam bentuk visual maupun verbal. Kemampuan representasi sangat penting dalam mempelajari fisika, karena representasi berhubungan dengan pemahaman konsep. Dibawah ini adalah salah satu soal bidang miring yang digunakan dalam penelitian ini 


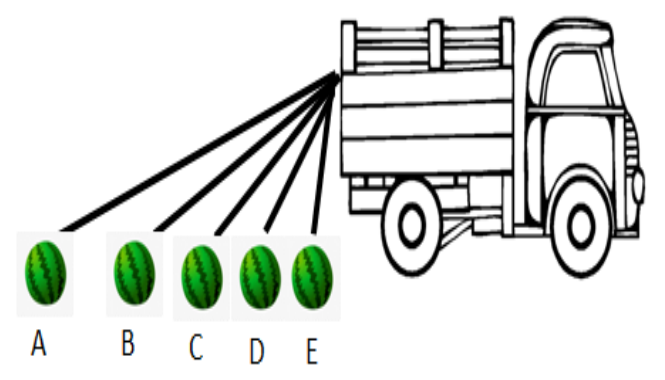

Hari ini pak Anton sedang panen semangka. Karena semangka akan dikirim ke distributor pak Anton berencana mengangkutnya dengan sebuah truk. Proses pemindahan semangka keatas truk yang paling mudah adalah........

Berikan penjelasanmu

Pada soal ini siswa dihadapkan dengan 2 permasalahan yaitu mengenai representasi visual dan verbal. Repesentasi visual berupa gambar dan representasi verbal berupa penjelasan oleh siswa. Hal tersebut dilakukan oleh peneliti bertujuan untuk menggali lebih lanjut jawaban siswa. Ada 2 kemungkinan yang terjadi yaitu siswa paham konsep atau siswa menjawab berdaarkan intuisi yang dimiliki. Berdasarkan analisis jawaban dari sebanyak 26 siswa, hanya 12 orang yang dapat menjawab benar soal dalam bentukvisual (gambar). Namun setelah dikoreksi jawaban siswa pada soal verbal, beberapa siswa menjawab tidak sesuai dengan konsep yang benar. Hal ini sejalan dengan penelitian Dimas dkk (2016), bahwa ketika siswa dihadapkan dengan 2 permasalahan represetasi yang berbeda dengan konsep yang sama, siswa dapat mengalami jawaban yang berbeda. Setelah peneliti melakukan wawancara, jawaban yang tidak konsisten dari siswa disebabkan oleh kebiasaan siswa dalam mempelajari fisika. Berikut adalah salah satu hasil wawancara dengan siswa :

Peneliti : Jelaskan jawaban anda di nomor 1!

Anda yakin dengan jawaban anda?

Siswa

: Saya yakin

Peneliti : Coba jelaskan!

Siswa : Jawaban saya D, karena gambar D menunjukkan Bidang Miring yang

Paling mudah digunakan untuk menaikkan semangka keatas truk.

Peneliti : Tapi mengapa disini anda memberikan penjelasan yang tidak spesifik, anda

Bisa mengatakan mudah itu karena bidang tersebut bagaimana?

Siswa : Saya pikir lebih mudah kalau papannya pendek, makanya saya menjawab

D.

Berdasarkan wawancara diatas dapat diketahui bahwa dalam menjawab soal, siswa cenderung menggunakan intuisi mereka. Mereka hanya membayangkan kemungkinan berdasarkan perasaan. Selain itu pengalaman siswa dalam kehidupan sehari-hari juga mamberikan pengaruh keyakinan siswa dalam menjawab soal. Hal ini mengakibatkan siswa memiliki pemahaman konsep yang rendah. Salah satu faktor yang mempengaruhi kurangnya pemahaman konsep siswa adalah intuisi. Pemahaman merupakan hal dasar yang harus dimiliki oleh siswa dalam mempelajari ilmu fisika. Ketika siswa memahami konsep maka siswa akan mudah dalam memahami soal dalam bentuk representasi. Berikut adalah salah satu soal katrol yang digunakan dalam penelitian ini 
A.
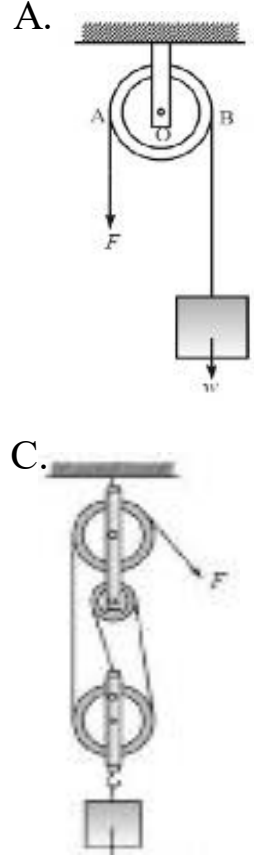

B.

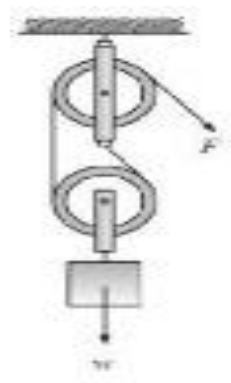

D.

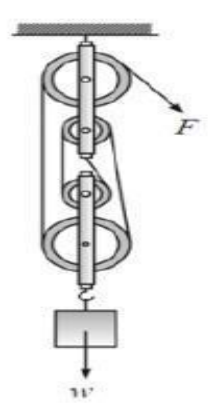

E.

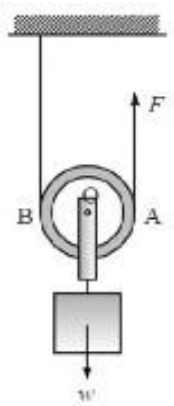

1.Pak Yudi mempunyai sumur untuk mengambil air disamping rumahnya. Sumur pak Yudi masih menggunakan timba/katrol untuk mengambil airnya. Agar pak Yudi dapat mengambil air dengan ringan, mana katrol yang paling mudah yang digunakan pak Yudi untuk mengangkat ember berisi air dari sumur?

Berikan penjelasanmu

Peneliti melakukan penelitian di sebuah sekolah yang berlokasi di desa. Sehingga soal ini merupakan hal yang sering dijumpai siswa dalam kehidupan sehari-hari. Pada soal materi katrol dari 26 siswa, hanya 8 siswa yang dapat menjawab dengan benar. 18 siswa lain memiliki jawaban yang salah. Setelah dikoreksi, dari 8 siswa memiliki penjelasan yang menarik untuk diketahui. Hal ini semakin menguatkan bahwa pemahaman konsep sangat dipengaruhi oleh intuisi siswa baik dari perasaan maupun keadaan lingkungan sekitar. Berikut adalah salah satu hasil wawancara dengan siswa:

Peneliti : Apa jawaban kamu pada soal ini?

Berika penjelasannya!

Siswa : Saya, menjawab A karena menurut saya gambar A merupakan gambar

Katrol menyerupai sumur timba seperti yang ada dirumah saya.

Hasil wawancara diatas siswa menyebutkan bahwa gambar yang disajikan sama dengan sumur yang ada dirumahnya, sehingga siswa menjawab berdasarkan pengalaman mereka. Hal ini adalah salah satu contoh pengalaman langsung siswa. Pengalaman ini dirasakan oleh siswa. sehingga ketika siswa dihadapkan dengan permasalahan yang sudah mereka lakukan, siswa akan menjawab berdasarkan perasaan (intuisi). Kesulitan dalam representasi verbal adalah karena ketidakmampuan siswa untuk memberikan penjelasan. Siswa masih mengalami kebingungan dalam menjelaskan sebuah konsep. Kelemahan dalam komunikasi verbal dapat menimbulkan miskomunikasi. Dalam ilmu fisika, kelemahan dalam komunikasi verbal dapat mengakibatkan miskonsepsi.

Berdasarkan hasil tes dan wawancara dengan siswa, dapat disimpulkan bahwa kemampuan representasi siswa masih rendah. Selain itu pemahaman konsep siswa juga masih kurang. Salah satu faktor rendahnya pemahaman siswa ini adalah kurangnya bimbingan guru dalam mempelajari fisika sebagai konsep. Guru hanya menekankan pada aspek matematis saja. Sehingga siswa beranggapan bahwa fisika identik dengan sebuah angka-angka yang harus dihitung dengan rumus. Hal ini ditemukan oleh peneliti berdasarkan dokumentasi yang dilakukan. Mempelajari fisika seharusnya berdasarkan konsep-konsep dasar yang mudah 
dipahami siswa sehingga siswa tidak beranggapan bahwa fisika itu sulit. Selain itu seringnya siswa dalam menggunakan intuisi dalam menyelesaikan permasalahan fisika adalah suatu permasalahan yang harus diperbaiki. Salah satu faktor terjadinya kesalahan konsep maupun miskonsepsi adalah intuisi.

\section{KESIMPULAN}

Kemampuan representasi merupakan salah satu aspek yang fundamental dalam mempelajari fisika. Representasi adalah tolak ukur untuk siswa sebagai ketercapaian mereka dalam memahami konsep fisika. Pentingnya representasi dalam permasalahan fisika harus ditingkatkan baik dari guru maupun siswa. Representasi akan memberikan pengalaman langsung kepada siswa dalam memahami konsep-konsep dalam ilmu fisika.

\section{SARAN}

Mengkaji permasalahan representasi dalam ilmu fisika sebaiknya semakin ditingkatkan. Saran untuk kedepannya yaitu untuk melakukan penelitian dalam aspek representasi pada materi lainnya. Sehingga semakin banyak kajian tentang representasi akan menjadi acuan untuk guru dalam meningkatkan kegiatan pembelajaran.

\section{DAFTAR PUSTAKA}

A. Izsak and M.G. Sherin, School Science and Mathematics, 103, 18 (2003).

A. R. C. Dewi, N. M. D. Putra, and Susilo, Analysis of graphic representation ability in oscillation phenomena, IOP Conference Series: Journal Of Physics , 983012024 (2018).

B. Waldrip, V Prain, and J Carolan, Electronic Journal of Science Educational, 11, 87 (2006).

C. Wieman And S Gilbert, Microbe 10 (5), 152-156 (2015).

D.E. Meltzer, American Journal of Physics, 73 (5), 463 (2005).

F. Reif, American Journal of Physics, 63 (1) , 17 (1995)

Hamalik, Oemar. 2011. Kurikulum dan Pembelajaran. Jakarta: Bumi Aksara

Muhibbin Syah.2013, Psikologi Pendidikan,Dengan Pendekatan Baru , Bandung PT Remaja Rosdakary

N. Erceg and I. Aviani, Croatian Journal of education. 16 43-80 (2012)

R.E. Mayer, Learning and Instruction, 13, 125-139 (2003).

S. Ainsworth, Learning and Instruction, 16, 183-198 (2006).

Dimas, A, Cari, Suparmi, Jeffry handhika (2017). International Journal of Science and Applied Science: Conference Series. Vol. 1 No. 1 40-44 